\title{
PERSEPSI MAHASISWA TERHADAP LEARNING MANAGEMENT SYSTEM (LMS): PENGARUH LOKASI, PERANGKAT DAN ANALISIS KEPUASAN MAHASISWA
}

\section{STUDENT PERCEPTIONS OF LEARNING MANAGEMENT SYSTEM (LMS): THE INFLUENCE OF LOCATION, TOOLS AND STUDENT SATISFACTION ANALYSIS}

\author{
Andi Saputra ${ }^{1}$, Susiana ${ }^{2}$ \\ ${ }^{1,2}$ Universitas Andalas \\ Kampus Unand Limau Manis, Padang, Indonesia \\ 1'andisaputra@adm.unand.ac.di; ${ }^{2}$ susiana@eb.unand.ac.id \\ Diterima tgl. 10/12/2020; Direvisi tgl. 02/06/2021; Disetujui tgl.04/06/2021
}

\begin{abstract}
LMS is one of the online learning models that are applied as online learning media in universities. This model isbelieved to overcome the high cost of internet packages incurred by students when using online meeting applications. This study aims to measure the level of student satisfaction and perception with the Ilearn application, with the Moodle platform, which Andalas University uses. Student perceptions were measured using six categories, which were analyzed based on gender, year of entry, location of residence, and the device used using the one way Anova method. After being measured using 5 Likert scales, it was concluded that the level of satisfaction and material uptake was in a low category (2.87). Whereas other categories are at a sufficient level, student interaction with lecturers (3.01), interaction with fellow students (3.12), devices and internet access (3.28), learning motivation (3.27), active student participation. (3.21). In addition, it was also concluded that there was no effect of gender, location, and the tools used on the level of satisfaction and uptake of lecture materials because the probability test results were greater than 0.05. While the year of entry affects the level of satisfaction felt by students with significant test results $<=0.05$.
\end{abstract}

Keywords: Learning Management System, Ilearn, Student Perceptions, Online Learning

\begin{abstract}
ABSTRAK
LMS merupakan salah satu dari sekian banyak model pembelajaran daring yang diterapkan sebagai media pembelajaran daring di perguruan tinggi. Model ini diyakini bisa mengatasi mahalnya biaya paket internet yang dikeluarkan oleh mahasiswa pada saat menggunakan aplikasi meeting online. Penelitian ini bertujuan untuk mengukur tingkat kepuasan yang dirasakan oleh mahasiswa terhadap aplikasi Ilearn dengan platfom Moodle yang digunakan oleh Universitas Andalas. Persepsi mahasiswa diukur menggunakan enam kategori yang dianalisis berdasarkan gender, tahun masuk, lokasi tempat tinggal, dan perangkat yang digunakan menggunakan metode one way Anova. Setelah diukur menggunakan lima skala likert, disimpulkan bahwa tingkat kepuasan dan serapan materi berada pada kategori rendah (2,87), sedangkan untuk kategori lain berada pada level cukup, interaksi mahasiswa dengan dosen $(3,01)$, interaksi dengan sesama mahasiswa $(3,12)$, perangkat dan akses internet $(3,28)$, motivasi belajar $(3,27)$, serta partisipasi aktif selama perkuliahan $(3,21)$. Setelah dilakukan uji signifikan, tidak ditemukan adanya pengaruh gender, lokasi, dan perangkat yang digunakan terhadap tingkat kepuasan dan serapan materi perkulihan. Hal ini ditunjukkan dengan hasil uji probabilitasnya lebih besar dari 0,05 , sedangkan tahun masuk berpengaruh terhadap tingkat kepuasan yang dirasakan mahasiswa dengan hasil uji signifikan $<=0,05$.
\end{abstract}

Kata Kunci: Learning Management System, Ilearn, Persepsi Mahasiswa, Kuliah Daring

\section{PENDAHULUAN}

Sejak merebaknya wabah pandemi Covid 19, penyelenggaraan pendidikan dan aktivitas perkantoran lebih banyak diselenggarakan dari rumah (Menteri Pendidikan dan Kebudayaan RI, 2020) yang menyebabkan meningkatnya intensitas penggunaan internet di masyarakat. Salah satu faktornya adalah kegiatan pembelajaran secara daring. Media pembelajaran yang digunakan sangat beragam, ada yang menggunakan media sosial, aplikasi online meeting, seperti Zoom, Webex, 
Microsoft Team, Google Meeting, dan aplikasi Learning Management System (LMS), seperti Moodle, dan Google Classroom.

Pada masa awal penerapan kuliah daring, banyak para pengajar, terutama di perguruan tinggi, yang menggunakan aplikasi meeting online. Hal ini cukup memberatkan bagi peserta didik. Mereka mengeluhkan tingginya biaya yang dikeluarkan untuk membeli paket internet dan tidak meratanya koneksi internet di beberapa wilayah Indonesia (Rahman, 2020; Utami \& Cahyono, 2020). Pimpinan di beberapa perguruan tinggi menuntut untuk tetap menyelenggarakan perkuliahan secara tatap muka melalui virtual sehingga perkuliahan tidak berjalan dengan maksimal, terutama untuk metode video conference. Untuk mengantisapi permasalahan tersebut, sebagian pimpinan perguruan tinggi akhirnya mengambil kebijakan dengan mewajibkan para dosen untuk memanfaatkan aplikasi LMS termasuk di Universitas Andalas (Unand) yang menggunakan aplikasi Ilearn dengan platfom Moodle (Arif et al., 2020).

Berbagai penelitian telah dilakukan terkait dengan LMS, baik dari perspektif peserta didik maupun pengajar. Penelitian Kc (2017) melakukan penelitian untuk menguji fitur Moodle dengan meminta tanggapan dosen universitas terkait dengan fitur apa saja yang paling banyak diadaptasi dan digunakan dalam perkuliahan dengan melakukan penelitian eksperimen terhadap mahasiswa untuk melihat pengaruh aplikasi Moodle terhadap aktivitas belajar online (Simanullang \& Rajagukguk, 2020). Penelitian tersebut menyimpulkan bahwa LMS berbasis Moodle dapat meningkatkan aktivitas belajar siswa walaupun dilakukan secara online. Sheshasaayee \& Bee (2017) melakukan studi evaluasi peran LMS Moodle untuk membantu akademisi dalam menciptakan komunitas pembelajaran online yang efektif berdasarkan pengalaman pengguna dengan menggunakan teknik data mining.

Penelitian ini bertujuan untuk mengukur persepsi dan tingkat kepuasan yang dirasakan mahasiswa terhadap penerapan LMS menggunakan aplikasi Ilearn berbasis Moodle yang digunakan di Universitas Andalas. Penelitian terkait yang telah dilakukan, di antaranya Koh \& Kan (2020) yang mengevaluasi kepuasan siswa terhadap kualitas sistem, kualitas informasi, dan kualitas layanan, pedagogis, kualitas pembelajaran, dan kualitas interaksi serta bagaimana frekuensi penggunaan mempengaruhi persepsi siswa terhadap kualitas LMS berdasarkan pengalaman pembelajaran atau frekuensi penggunaan LMS. Hasil penelitian menunjukkan kepuasan terhadap kualitas informasi secara signifikan berpengaruh terhadap pengguna dengan frekuensi jarang dan rata-rata, kepuasan terhadap sistem berpengaruh signifikan terhadap pengguna dengan frekuensi rata-rata dan sering, sedangkan kualitas hasil pembelajaran berpengaruh signifikan terhadap tingkat kepuasan mahasiswa dengan frekuensi penggunaan sering. Alenezi (2018) telah mengidentifikasi berbagai hambatan yang menghalangi penerapan LMS di universitas Arab Saudi. Hasil penelitiannya mengungkapkan bahwa hambatan utama penggunaan LMS adalah (a) dukungan teknis yang tidak memadai dari universitas, (b) sikap negatif terhadap teknologi, (c) pelatihan penggunaan platform LMS yang tidak memadai, (d) akses Internet dan jaringan yang buruk, (e) infrastruktur yang terbatas untuk mendukung LMS, (f) kurangnya perangkat keras dan perangkat lunak untuk menjalankan LMS, dan (f) kemampuan bahasa Inggris. Horvat et al. (2015) meneliti tentang kualitas dan karakteristik dari LMS Moodle dan perbedaan tingkat kepuasan peserta didik terkait dengan karakteristik tersebut. Komponen karakteristik kualitas yang diteliti, seperti waktu tunggu rata-rata untuk tanggapan, kualitas umpan balik, ketelitian materi, kejelasan materi, keramahan pengguna situs web, keragaman kerja sama, dan kuantitas materi. Penelitian ini menyimpulkan bahwa tidak ada perbedaan kepuasan berdasarkan jenis kelamin, sedangkan jika dilihat berdasarkan usia dan tahun studi mereka, terdapat perbedaan secara signifikan tingkat kepuasan mahasiswa terhadap kualitas dan karakteristik Moodle. Alqurashi (2019) meneliti tentang tingkat kepuasan yang dirasakan oleh mahasiswa untuk mengevaluasi pembelajaran secara daring 
menggunakan beberapa indikator. Indikator tersebut terdiri dari learning self-efficacy (OLSE), learner-content interaction (LCI), learner-instructor interaction (LII), and learner-learner interaction (LLI). Studi ini menyimpulkan bahwa LCI adalah prediktor kepuasan siswa yang paling kuat dan paling signifikan, disusul oleh OLSE. Selain itu, LLI tidak diprediksi sebagai indikator yang mempengaruhi tingkat kepuasan yang dirasakan oleh mahasiswa dalam pembelajaran daring. Rahmadi \& Hayati (2020) melakukan kajian secara kritis terhadap kebutuhan pengembangan Digital Literacy Massive Open Online Courses (DL-MOOCs) di perguruan tinggi tentang penggunaan LMS menggunakan Technology Acceptance Model (TAM). Hasil penelitian menunjukkan persepsi positif mahasiswa terhadap penggunaan LMS, tetapi masih ada kendala teknis yang harus ditangani untuk memastikan bahwa LMS dapat berfungsi secara efektif.

Penelitian ini sedikit berbeda dengan penelitian-penelitian sebelumnya karena persepsi dan tingkat kepuasan mahasiswa diukur dengan menggabungkan instrumen hambatan dan pengukuran persepsi. Kepuasan pengguna diukur dengan cara menguji hubungan antara variabel dependen dengan independen. Variabel dependen yang diukur terdiri dari lima kriteria: (a) interaksi mahasiswa dengan dosen, (b) interaksi sesama mahasiswa, (c) perangkat dan koneksi internet, (d) motivasi belajar, (e) partisipasi selama mengikuti perkuliahan, dan (e) tingkat kepuasan mahasiswa terhadap aplikasi secara keseluruhan, dan tingkat serapan terhadap materi pembelajaran. Selain itu, variabel independen yang diyakini secara signifikan mempengaruhi tingkat kepuasan mahasiswa dalam mengikuti pembelajaran secara daring: (a) jenis kelamin, (b) tahun masuk, (c) perangkat yang digunakan, dan (d) lokasi pada saat mengikuti perkuliahan.

Penelitian ini penting dilakukan karena aplikasi Ilearn sudah digunakan sejak tahun 2006 di Universitas Andalas. Kebijakan kuliah daring telah meningkatkan penggunaan aplikasi ini sebagai media pendukung pembelajaran. Kemudian, bagaimana kalau aplikasi ini digunakan oleh banyak orang secara bersamaan karena kebijakan kuliah daring? Begitu juga pengaruh biaya dan koneksi internet yang banyak dikeluhkan selama ini karena tidak meratanya kualitas jaringan internet di beberapa daerah di Indonesia (Rahman, 2020; Utami \& Cahyono, 2020).

\subsection{Kerangka Penelitian}

Penelitian ini bertujuan untuk mengetahui dan menganalisis tentang tingkat kepuasan mahasiswa terhadap program pembelajaran online menggunakan aplikasi LMS, khususnya aplikasi Ilearn yang dikembangkan menggunakan platform Moodle yang sudah digunakan di Universitas Andalas sejak tahun 2006 yang lalu (Arif et al., 2020). Untuk mencapai tujuan ini, penulis mengelompokkan sampel ke dalam beberapa kategori demografis (gender, tahun masuk, lokasi tempat tinggal, dan perangkat yang digunakan untuk mengakses aplikasi Ilearn). Tujuannya adalah untuk menentukan apakah ada pengaruh dari variabel-variabel tersebut, sehingga menghasilkan perbedaan tingkat kepuasan secara signifikan terhadap kinerja aplikasi Ilearn.

Selanjutnya penulis mencoba membuat beberapa hipotesis, terkait dengan pengaruh variabel demografis tersebut, yang terdiri dari:

H1: Tingkat kepuasan yang dirasakan mahasiswa terhadap kualitas aplikasi LMS Ilearn cukup rendah.

Untuk membuktikannya, penulis mengukurnya dengan menghitung secara keseluruhan nilai instrumen dari variabel dependen menggunakan metode statistik deskriptif dan mencari rata-rata nilai dari setiap variabel/kategori.

H2: Tidak ada perbedaan tingkat kepuasan secara signifikan antara laki-laki dan perempuan terhadap kualitas LMS Ilearn. 
Untuk membuktikan ini, hubungan antara jenis kelamin dengan variabel tingkat kepuasan mahasiswa pada varibel kepuasan keseluruhan dan tingkat serapan terhadap materi pembelajaran dianalisis untuk melihat tingkat signifikansinya.

H3: Tahun masuk mempengaruhi secara signifikan tingkat kepuasan yang dirasakan mahasiswa terhadap kualitas aplikasi LMS Ilearn. Semakin lama mahasiswa mengikuti perkuliahan maka tingkat kepuasannya semakin tinggi.

Untuk membuktikan ini, hubungan antara tahun masuk yang terdiri dari 3 kelompok, yaitu angkatan 2018-2020 dengan variabel tingkat kepuasan mahasiswa pada varibel kepuasan keseluruhan dan tingkat serapan terhadap materi pembelajaran dianalisis untuk melihat tingkat signifikansinya.

H4: Lokasi tempat mahasiswa berdomisili mempengaruhi secara signifikan tingkat kepuasan yang dirasakan mahasiswa terhadap kualitas aplikasi LMS Ilearn. Mahasiswa yang berdomisili di ibukota propinsi tingkat kepuasannya lebih tinggi dibandingkan dengan yang tinggal di kecamatan/desa.

Untuk membuktikan ini, hubungan antara lokasi tempat tinggal yang terdiri dari 3 kelompok, yaitu ibukota propinsi, ibukota kabupaten/kota, dan kecamatan/desa dengan variabel tingkat kepuasan mahasiswa pada varibel kepuasan keseluruhan dan tingkat serapan terhadap materi pembelajaran dianalisis untuk melihat tingkat signifikansinya.

H5: Perangkat yang digunakan untuk mengakses aplikasi mempengaruhi secara signifikan tingkat kepuasan yang dirasakan mahasiswa terhadap kualitas aplikasi LMS Ilearn. Mahasiswa yang menggunakan Laptop dan HP, tingkat kepuasannya lebih tinggi dibandingkan dengan mereka yang hanya menggunakan laptop, atau HP saja.

Untuk membuktikan ini, hubungan antara perangkat yang digunakan dengan variabel tingkat kepuasan mahasiswa pada varibel kepuasan keseluruhan dan tingkat serapan terhadap materi pembelajaran dianalisis untuk melihat tingkat signifikansinya.

Berdasarkan hipotesis tersebut, dapat diambil keputusan dengan ketentuan berikut.

Jika probabilitas < 0.05 maka H0 diterima, tingkat kepuasan dipengaruhi oleh gender, lokasi, perangkat, dan tahun masuk.

Jika probabilitas > 0.05 maka H0 ditolak, tingkat kepuasan tidak dipengaruhi oleh gender, lokasi, perangkat, dan tahun masuk.

\section{METODE PENELITIAN}

\subsection{Responden dan Karakteristik Sampel}

Penelitian ini menggunakan metode kuantitatif untuk menganalisis manfaat yang dirasakan oleh mahasiswa selama mengikuti pembelajaran secara daring menggunakan aplikasi Ilearn yang dikembangkan menggunakan platform Moodle di kampus Unand. Pengumpulan data dilakukan menggunakan kuesioner yang dibagikan kepada mahasiswa Unand yang telah dan sedang menggunakan aplikasi Ilearn dalam perkuliahan. Responden merupakan mahasiswa angkatan 20182020. Mereka dipilih karena angkatan 1 sampai dengan 3 merupakan mahasiswa yang aktif dan paling banyak mengikuti perkuliahan daring.

Metode pengambilan sampel menggunakan Random Puposive Sampling dengan membagikan kuesioner online yang dibuat menggunakan Google Form secara acak ke mahasiswa melalui dosen pengampu mata kuliah. Informasi alamat kuesioner/link dibagikan melalui whatsapp grup perkuliahan sehingga kuesioner bisa sampai ke tangan responden yang tepat. Sampel terpilih mewakili seluruh jenjang studi yang ada di Unand, yaitu diploma III, sarjana, dan pascasarjana. Selain itu, responden juga mewakili fakultas bidang sains dan teknologi, dan sosial humaniora. 
Dari total 30.437 mahasiswa terdaftar (Biro Administrasi Akademik dan Kemahasiswaan, 2020) setelah dilakukan perhitungan jumlah sampel menggunakan rumus Slovin dengan margin of error $10 \%$, diperoleh jumlah minimal sampel sebanyak 99,67.

\subsection{Instrumen}

Kuesioner yang digunakan dalam penelitian ini terdiri atas tiga bagian. Bagian pertama berisi pertanyaan tentang demografis responden: gender, tahun masuk, lokasi tempat tinggal pada saat mengikuti kuliah daring dan peralatan yang digunakan untuk mengakses materi kuliah. Bagian kedua berisi pertanyaan tentang persepsi mahasiswa terhadap kualitas aplikasi Ilearn yang dirasakan oleh mahasiswa yang terdiri 26 pertanyaan yang dikelompokkan ke dalam enam kategori: (a) interaksi mahasiswa dengan dosen; (b) interaksi dengan sesama mahasiswa; (c) perangkat dan akses internet; (d) motivasi belajar; (e) partisipasi selama perkuliahan; dan (f) Tingkat kepuasan dan serapan materi perkuliahan secara keseluruhan.

Semua pertanyaan tersebut diadopsi dari berbagai penelitian terdahulu. Untuk pertanyaan kategori A dan B diadopsi dari penelitian (Kuo et al., 2014), untuk kategori C, dan D diadopsi dari penelitian (Muilenburg \& Berge, 2005), untuk variabel E, dan $\mathrm{F}$ diadopsi dari penelitian (Alqurashi, 2019). Penilaian instrumen menggunakan lima skala likert, mulai dari 1 (tidak puas) sampai dengan 5 (sangat puas).

Bagian ketiga dari kuesioner adalah menjaring saran mahasiswa terkait dengan kinerja aplikasi Ilearn dalam mendukung perkuliahan daring yang mereka rasakan selama ini.

\subsection{Metode Analisis Data}

Untuk mengukur tingkat kepuasan mahasiswa terhadap Ilearn, data hasil penelitian dihitung menggunakan metode statistik deskriptif dengan mencari nilai mean, standar deviasi, dan $\mathrm{N}$ (jumlah data valid). Selanjutnya, nilai mean dihitung rata-ratanya perkategori untuk melihat tingkat kepuasan berdasarkan kategori/kelompok.

Selain itu, untuk melihat pengaruh data demografis terhadap tingkat kepuasan yang dirasakan mahasiswa, kategori $\mathrm{F}$ yang berisi tentang tingkat kepuasan secara menyeluruh dan serapan materi perkuliahan dianalisis menggunakan metode one way Anova dengan bantuan aplikasi SPSS ver. 24.

Terakhir penulis merangkum saran yang diberikan oleh mahasiswa terhadap kinerja penggunaan aplikasi Ilearn dalam mendukung proses pembelajaran secara daring di Unand.

\section{HASIL DAN PEMBAHASAN}

\subsection{Hasil}

Penelitian ini menganalisis tingkat kepuasan yang dirasakan oleh mahasiswa selama mengikuti perkuliahan daring menggunakan aplikasi Ilearn di kampus Unand. Setelah data penelitian dikumpulkan, terjaring sebanyak 248 data yang valid dari total 255 sampel yang masuk. Jumlah ini sudah melebihi minimal 99,67 sampel. Sampel sudah mewakili 3 jenjang studi yang ada di Unand, diploma III, sarjana, dan pascasarjana. Setelah dilakukan rekapitulasi terhadap seluruh kuesioner yang ada berdasarkan demografi: gender, tahun masuk, lokasi tempat tinggal responden, jenjang studi, dan perangkat yang digunakan untuk mengakses aplikasi Ilearn, hasilnya seperti terlihat pada Tabel 1.

Tabel 1. Rekapitulasi Data Responden Berdasarkan Demografi

\begin{tabular}{ccccc} 
Jumlah sampel & $: 248$ & & & \\
\hline Kategori & & Item & Jumlah & $\%$ \\
\hline
\end{tabular}




\begin{tabular}{llrr} 
Gender & Laki-laki & 71 & $28,63 \%$ \\
& Perempuan & 177 & $71,37 \%$ \\
Tahun masuk & 2018 & & \\
& 2019 & 59 & $23,79 \%$ \\
& 2020 & 65 & $26,21 \%$ \\
Lokasi & & 124 & $50,00 \%$ \\
& Ibukota propinsi & & \\
& Ibukota kab/kota & 60 & $24,19 \%$ \\
& Kecamatan/desa & 36 & $14,52 \%$ \\
& & 152 & $61,29 \%$ \\
Perangkat & HP dan Laptop & 170 & $68,55 \%$ \\
& Laptop & 6 & $2,42 \%$ \\
& HP & 72 & $29,03 \%$ \\
& D3 & 18 & $7,26 \%$ \\
& S1 & 214 & $86,29 \%$ \\
& Pascasarjana & 16 & $6,45 \%$ \\
\hline
\end{tabular}

Jika dilihat dari persentase jenis kelamin, tahun masuk, dan jenjang studi, proporsi untuk masing-masing kategori sudah sesuai dengan mewakili dari data mahasiswa terdaftar (Biro Administrasi Akademik dan Kemahasiswaan, 2020). Mayoritas responden berasal dari jenis kelamin perempuan, tahun masuk didominasi oleh mahasiswa tahun pertama (angkatan 2020), serta tingginya persentase mahasiswa jenjang studi S1.

Instrumen penelitian yang dibuat dalam bentuk kuesioner online, terdiri dari 26 butir pertanyaan yang dibagi ke dalam 6 kategori. Hasil rekapitulasi data kuesioner yang diisi oleh seluruh responden, kemudian dihitung menggunakan metode statistik deskriptif untuk mendapatkan mean, standar deviasi, dan jumlah data yang valid. Hasilnya seperti yang terlihat pada Tabel 2.

Tabel 2. Tingkat Kepuasan Berdasarkan Butir Pertanyaan

\begin{tabular}{|c|c|c|c|c|c|c|c|c|c|c|c|c|c|}
\hline \multirow{3}{*}{ Var } & \multicolumn{12}{|c|}{ Pertanyaan ke-n } & \multirow{3}{*}{$\begin{array}{c}\text { Rata- } \\
\text { rata } \\
\text { Mean }\end{array}$} \\
\hline & \multicolumn{2}{|c|}{1} & \multicolumn{2}{|c|}{2} & \multicolumn{2}{|c|}{3} & \multicolumn{2}{|c|}{4} & \multicolumn{2}{|c|}{5} & \multicolumn{2}{|c|}{6} & \\
\hline & Mean & $S d$ & Mean & $S d$ & Mean & $S d$ & Mean & $S d$ & Mean & $S d$ & Mean & $S d$ & \\
\hline A & 2,84 & 0,91 & 2,59 & 0,92 & 3,33 & 0,88 & 2,90 & 1,06 & 3,06 & 0,90 & 3,31 & 0,88 & 3,01 \\
\hline $\mathrm{B}$ & 2,94 & 1,03 & 3,15 & 0,85 & 3,17 & 0,94 & 3,10 & 0,89 & 3,26 & 0,97 & 3,10 & 0,87 & 3,12 \\
\hline $\mathrm{C}$ & 3,18 & 0,97 & 3,58 & 0,94 & 3,35 & 1,09 & 2,81 & 1,07 & 3,47 & 0,92 & & & 3,28 \\
\hline $\mathrm{D}$ & 3,13 & 0,92 & 3,55 & 0,90 & 3,23 & 0,90 & 3,19 & 0,87 & & & & & 3,27 \\
\hline $\mathrm{E}$ & 3,96 & 0,87 & 2,78 & 0,93 & 2,88 & 0,86 & & & & & & & 3,21 \\
\hline $\mathrm{F}$ & 2,90 & 0,89 & 2,84 & 0,63 & & & & & & & & & 2,87 \\
\hline
\end{tabular}

Berdasarkan hasil pada Tabel 2, dari 6 variabel utama yang diteliti, ternyata tingkat kepuasan tertinggi berada pada kategori perangkat dan akses internet $(3,28)$ dari skala 5 , dilanjutkan dengan motivasi belajar $(3,27)$, partisipasi perkuliahan $(3,21)$, interaksi sesama mahasiswa $(3,12)$, dan yang paling rendah variabel interaksi mahasiswa dengan dosen $(3,01)$. Semua variabel berada sedikit di atas level cukup. Sedangkan untuk varibel penilaian tingkat kepuasan dan serapan materi perkuliahan, masih sedikit dibawah level cukup $(2,87)$. 
Kalau dilihat lebih jauh lagi untuk masing-masing butir pertayaan, untuk kategori perangkat dan akses internet, yang mendapatkan tingkat kepuasan tertinggi ternyata standar deviasinya juga paling tinggi $(1,00)$ artinya sebaran nilai cukup jauh. Ternyata setelah dilihat nilai per butir pertanyaaan, ada perbedaan cukup jauh antara butir C4 (akses internet di tempat saya berjalan lancar) tingkat kepuasannya paling rendah $(2,81)$, selisihnya cukup jauh dengan butir C2 $(3,58)$, yaitu tentang kemudahan akses materi yang tersimpan di dalam Ilearn.

Untuk kategori motivasi belajar, nilai tertinggi pada butir D2 $(3,55)$, tentang kemudahan dalam mengulang pelajaran menggunakan Ilearn. Sedangkan nilai terendah, tentang kemudahan dalam berpartisipasi aktif dalam kegiatan pembelajaran, butir D4 (3,13).

Selanjutnya untuk partisipasi selama perkuliahan, kepuasan tertinggi pada butir E1 $(3,94)$, dimana mahasiswa mengaku mengikuti perkuliahan dari awal sampai akhir, merupakan nilai tertinggi dari seluruh butir pertanyaan yang ada pada kuesioner. Sedangkan untuk nilai terendah pada butir E2 $(2,78)$ fokus/kosentrasi dalam mengikuti perkuliahan menggunakan Ilearn.

Untuk variabel interaksi mahasiswa dengan dosen, kepuasan tertinggi pada butir A3 (3,33), dosen rutin mengirim pertanyaan untuk didiskusikan melalui Ilearn. Sedangkan nilai terendah pada butir A2 $(2,59)$, tentang kemudahan mahasiswa berinteraksi dengan dosen.

Selanjutnya variabel interaksi dengan sesama mahasiswa, tidak ada perbedaan yang cukup signifikan untuk dari 6 butir pertanyaan yang ada. Nilainya berkisar antara 3,10 -3,26.

\subsection{Analisis Pengaruh Gender, Tahun Masuk, Perangkat, dan Lokasi Terhadap Tingkat Kepuasan}

Untuk melihat pengaruh jenis kelamin, tahun masuk, lokasi tempat tinggal, dan perangkat yang digunakan terhadap tingkat kepuasan yang dirasakan oleh mahasiswa, dilakukan analisis menggunakan metode one way Anova. Dalam hal ini variabel yang diuji adalah tingkat kepuasan secara keseluruhan $(\mathrm{F} 1)$, dan serapan materi perkuliahan $(\mathrm{F} 2)$. hasilnya seperti terlihat pada Tabel 3.

Tabel 3. Tingkat Kepuasan Berdasarkan Kategori

\begin{tabular}{clrc}
\hline Kode & \multicolumn{1}{c}{ Kategori } & Mean & SD \\
\hline A & Interaksi mahasiswa dengan dosen & 3,01 & 0,93 \\
B & Interaksi dengan sesama mahasiswa & 3,12 & 0,93 \\
C & Perangkat dan akses internet & 3,28 & 1,00 \\
D & Motivasi belajar & 3,27 & 0,90 \\
E & Partisipasi selama perkuliahan & 3,21 & 0,94 \\
F & Persepsi dan serapan materi & 2,87 & 0,64 \\
\hline
\end{tabular}

Variabel tahun masuk, tingkat kepuasan mahasiswa angkatan 2020 paling tinggi dibandingkan dengan angkatan lainnya, dengan nilai 3,02, angkatan 2019 (2,89), dan angkatan 2018 dengan tingkat kepuasan terendah $(2,64)$. Setelah dilakukan uji probabilitas hasilnya untuk variabel F1 adalah 0,026artinya signifikan $<0,05$ yang menandakan bahwasanya tahun masuk berpengaruh terhadap tingkat kepuasan yang dirasakan mahasiswa terhadap aplikasi Ilearn. Sedangkan untuk variabel $\mathrm{F} 2$, hasil uji probabilitasnya adalah $0,408(>0.50)$ yang berarti tahun masuk tidak mempengaruhi tingkat serapan mahiasiswa terhadap materi perkuliahan menggunakan Ilearn.

Kalau dilihat berdasarkan lokasi atau domisili mahasiswa, rata-rata tingkat kepuasan juga berada dibawah kategori cukup, yaitu 2,88. Kepuasan tertinggi untuk kategori 2 (ibukota kab/kota) dengan nilai 2,97, disusul oleh mahasiswa yang tinggal di kecamatan/desa $(2,91)$, dan ibukota 
propinsi $(2,75)$. Sedangkan hasil uji probabilitas, semuanya $>0.50$ yang berarti, baik lokasi maupun perangkat tidak mempengaruhi variabel F1 dan F2.

Analisis selanjutnya berdasarkan perangkat yang digunakan, hasil probabilitasnya signifikan $>0,05$, artinya tidak ada pengaruh perangkat terhadap tingkat kepuasan dan serapan materi perkuliahan, seperti terlihat pada Tabel 4.

Tabel 4. Hasil Uji Pengaruh Tahun Masuk, Lokasi, Perangkat, dan Gender

\begin{tabular}{ccccccccccccc}
\hline Var & \multicolumn{3}{c}{ Tahun Masuk } & \multicolumn{3}{c}{ Lokasi } & \multicolumn{4}{c}{ Perangkat } & \multicolumn{3}{c}{ Gender } \\
& Item & Mean & Sig. & Item & Mean & Sig. & Item & Mean & Sig. & Item & Mean & Sig. \\
\hline \multirow{4}{*}{ F1 } & 2018 & 2,64 & 0,026 & 1 & 2.75 & 0,407 & 1 & 2.82 & 0,203 & 0 & 2,9 & 0,889 \\
& 2019 & 2,89 & & 2 & 2.97 & & 2 & 3.17 & & 1 & 2,89 & \\
& 2020 & 3,02 & & 3 & 2.91 & & 3 & 3.01 & & & & \\
\hline \multirow{3}{*}{ F2 } & 2018 & 2,75 & 0,408 & 1 & 2.77 & 0,426 & 1 & 2.84 & 0,408 & 0 & 2,82 & 0,523 \\
& 2019 & 2,86 & & 2 & 2.77 & & 2 & 3.00 & & 1 & 2,88 & \\
& 2020 & 2,88 & & 3 & 2.88 & & 3 & 2.80 & & & & \\
\hline
\end{tabular}

Begitu juga dengan pengaruh gender, tidak ada perbedaan yang signifikan antara mahasiswa laki-laki dan perempuan terhadap tingkat kepuasan aplikasi Ilearn secara keseluruhan, dan tingkat serapan materi perkuliahan.

Untuk mendapatkan feedback terkait dengan metode pelaksanaan perkuliahan, responden juga diajukan pertanyaan terbuka, berupa saran mereka terhadap kinerja aplikasi Ilearn yang sudah digunakan. Hasilnya seperti terlihat pada Tabel 5.

Tabel 5. Saran Terhadap Kinerja Aplikasi Ilearn

\begin{tabular}{|c|c|c|c|}
\hline No. & Saran & Jumlah & $\%$ \\
\hline 1 & $\begin{array}{l}\text { Ilearn sering mengalami error, terutama pada saat } \\
\text { melakukan pengisian absen }\end{array}$ & 75 & 30,24 \\
\hline 2 & $\begin{array}{l}\text { Sebaiknya dilakukan perkuliahan tatap } \\
\text { muka/offline }\end{array}$ & 34 & 13,71 \\
\hline 3 & Sebaiknya menggunakan WA grup atau zoom & 15 & 6,05 \\
\hline 4 & Jawaban lainnya & 68 & 27,42 \\
\hline \multirow[t]{2}{*}{5} & Tidak memberikan saran & 58 & 23,39 \\
\hline & Total & 248 & \\
\hline
\end{tabular}

Setelah dilakukan seleksi, dari sekian banyak saran yang disampaikan oleh mahasiswa, ada 3 jenis saran yang cukup banyak disampaikan oleh responden atau mahasiswa. Saran terbanyak yang disampaikan adalah terkait dengan kinerja aplikasi Ilearn sering mengalami error, terutama pada saat diakses secara bersamaan, selanjutnya permintaan untuk diadakannya perkuliahan tatap muka, serta usulan untuk memanfaatkan media sosial sebagai media pembelajaran alternatif.

\subsection{Pembahasan}

Berdasarkan data pada Tabel 2, terlihat bahwa secara keseluruhan persepsi dan tingkat kepuasan mahasiswa terhadap kinerja aplikasi Ilearn masih berada pada kategori cukup. Tingkat kepuasan tertinggi diperoleh dari kategori C (Perangkat dan Akses Internet) dengan nilai 3,28, sedangkan yang terendah pada kategori F (Persepsi Keseluruhan dan Serapan Materi) yang hanya 2,87. Kondisi ini sesuai dengan prediksi awal yang dituangkan dalam hipotesis 1 , bahwasanya tingkat kepuasan mahasiswa terhadap kinerja aplikasi Ilearn cukup rendah. 
Untuk kategori $\mathrm{C}$ standar deviasinya ternyata paling tinggi dibandingkan dengan kategori lainnya, artinya sebaran nilai cukup tinggi atau selisih nilai mean yang dihasilkan antara nilai tertinggi, dan terendah cukup jauh. Setelah dilihat data Pada Tabel 3, terjadi perbedaan yang signifikan antara butir C2 (nilai tertinggi), dengan butir C4 (nilai terendah), yaitu mahasiswa menganggap materi kuliah yang tersimpan di dalam aplikasi Ilearn bisa diakses dengan mudah, sesuai dengan hasil penelitian (Alqurashi, 2019) yang menyatakan bahwasanya interaksi mahasiswa dengan materi perkuliahan merupakan prediktor kepuasan paling kuat dan signifikan.

Sebaliknya mahasiswa menganggap akses internet di tempatnya tidak berjalan dengan lancar, makanya butir C4 mendapatkan nilai paling rendah. Artinya pada kategori ini mahasiswa cukup puas dengan kemudahan dalam mengakses materi perkuliahan, akan tetapi terkendala pada kelancaran koneksi internet pada saat menjalani perkuliahan daring, dan tidak meratanya koneksi internet di beberapa daerah (Sadikin \& Hamidah, 2020; Yudiawan, 2020).

Akan tetapi, ada sedikit perbedaan dari hasil penelitian (Sadikin \& Hamidah, 2020), yang menyimpulkan pembelajaran secara daring secara signifikan mampu meningkatkan motivasi belajar. Hasil penelitiannya tidak menunjukkan adanya peningkatan secara signifikan dari motivasi belajar mahasiswayang paling menonjol mereka rasakan hanyalah dari segi kemudahan dalam mengulang pelajaran. Setelah diteliti lebih lanjut, tidak ada pembahasan yang menunjukkan tentang peningkatan motivasi belajar dalam penelitian (Sadikin \& Hamidah, 2020) tersebut. Rujukan yang diambil sangat lemah, pertama dari penelitian (Sobron A. N, 2019), dengan sampel hanya sebanyak 26 orang siswa SD, itupun diambil secara bebas, tanpa ada pendampingan, kedua dari penelitian (Aulia \& Aina, 2016), yang ini justru meneliti tentang dampak penerapan multimedia interaktif dalam pembelajaran, bukan tentang pembelajaran daring.

Hal yang sama juga terjadi pada kategori E (Partisipasi Selama Perkuliahan). Respon tertinggi pada butir E1, dengan nilai 3,96 (setuju), dimana mahasiswa mengaku mengikuti perkuliahan dari awal sampai akhir. Akan tetapi sebaliknya pada butir E2, tentang kosentrasi belajar, ternyata nilainya sangat rendah, yaitu 2,78. Walaupun tingkat partisipasi mahasiswa cukup tinggi pada saat mengikuti perkuliahan menggunakan Ilearn, kosentrasi belajarnya cukup rendah. Kondisi ini kemungkinan besar dipengaruhi oleh perilaku masyarakat yang cenderung mengakses konten media sosial di internet (Rustam, 2017) sehingga mempengaruhi kosentrasi mahasiswa dalam mengikuti pembelajaran secara daring.

Dalam penelitian ini tidak ditemukan adanya pengaruh secara signifikan dari perbedaan gender terhadap tingkat kepuasan yang dirasakan secara keseluruhan dan tingkat serapan materi perkuliahan, sesuai dengan hasil penelitian (Horvat et al., 2015). Begitu juga dengan pengaruh lokasi pada saat mahasiswa mengikuti perkuliahan, yang menandakan bahwasanya tidak ada perbedaan secara signifikan pada kualitas koneksi internet di wilayah Sumatera Barat, antara wilayah perkotaan dan pedesaan walaupun secara keseluruhan mahasiswa merasakan kendala terkait dengan kualitas koneksi internet.

Begitu juga dengan pengaruh perangkat yang digunakan dalam menjalani perkuliahan, tidak ada perbedaan secara signifikan. Hal ini dipengaruhi karena mayoritas mahasiswa (Tabel 1) sudah menggunakan Laptop dan HP dalam mengikuti dan mengakses materi perkuliahan. Sehingga mahasiswa setuju dengan pernyataan pada butir C5 (spesifikasi perangkat yang digunakan tidak terlalu mahal). Hasil ini membuktikan hipotesis 2, 4, dan 5 tidak sepenuhnya benar. Untuk Hipotesis 4 terkait dengan masalah akses internet, justru kendala yang dialami hampir merata di setiap lokasi. 
Tahun masuk ternyata berpengaruh secara signifikan terhadap kepuasan yang dirasakan oleh mahasiswa. Tingkat kepuasan yang dirasakan mahasiswa semakin menurun seiring bertambahnya masa studi. Hasil penelitian ini bekorelasi dengan penelitian (Koh \& Kan, 2020) yang menyatakan bahwasanya persepsi mahasiswa dipengaruhi oleh frekuensi penggunaan aplikasi. Akan tetapi berbeda dengan hasil penelitian (Horvat et al., 2015) yang sebaliknya menyimpulkan bahwasanya tingkat kepuasan terhadap aplikasi Moodle akan meningkat seiring dengan semakin banyaknya perkuliahan yang diikuti. Fakta ini bertolak belakang dengan Hipotesis 3 yang memperkirakan bahwa mahasiswa tahun lama tingkat kepuasannya akan lebih tinggi dibandingkan dengan mahasiswa baru.

Secara keseluruhan tingkat kepuasan mahasiswa Unand terhadap aplikasi Ilearn yang digunakan sebagai media pendukung pembelajaran cukup rendah, begitu juga dengan serapan materi perkuliahan. Salah satu penyebabnya adalah seringnya terjadi kendala atau error, terutama pada saat aplikasi ini diakses oleh banyak orang di waktu bersamaan. Hal ini terlihat pada kolom saran yang diisi oleh mahasiswa (Tabel 5), aplikasi sering mengalami error pada saat pengisian absensi. Hasil ini selaras dengan penelitian (Juhary, 2014) yang menyatakan bahwasanya kendala teknis merupakan salah satu faktor yang sangat penting dalam mendukung aplikasi LMS agar bisa berjalan dengan efektif. Kendala teknis ini kemungkinan disebabkan karena kapasitas server yang masih rendah sehingga tidak mampu melayani permintaan akses yang cukup tinggi pada saat bersamaan.

\section{PENUTUP}

Dari keseluruhan kriteria penilaian, tingkat kepuasan yang cukup tinggi dirasakan pada kategori perangkat dan akses internet, yaitu faktor kemudahan dalam mengakses materi perkuliahan yang tersimpan di dalam aplikasi dan perangkat yang digunakan untuk mengakses Ilearn tidak berbiaya mahal. Sebaliknya dari sisi kelancaran akses internet, tingkat kepuasannya cukup rendah. Untuk kategori motivasi belajar hasilnya juga berada pada kategori cukup, karena faktor kemudahan dalam mengulang materi pelajaran yang ada di dalam aplikasi Ilearn. Selain itu, tidak ada pengaruh yang signifikan dari lokasi tempat tinggal pada saat mengikuti perkuliahan, perangkat yang digunakan, dan jenis kelamin terhadap kepuasan yang dirasakan mahasiswa. Akan tetapi tahun masuk berpengaruh cukup signifikan, dimana tingkat kepuasan mahasiswa cenderung menurun seiring dengan bertambahnya masa studi. Dari penelitian ini dapat disimpulkan bahwasanya secara keseluruhan tingkat kepuasan dan serapan materi kuliah yang dirasakan oleh mahasiswa Unand terhadap kinerja aplikasi Ilearn selama menjalani pembelajaran secara daring cukup rendah. Kendala teknis merupakan salah satu faktor penyebabnya karena aplikasi LMS sering mengalami error pada saat diakses secara bersamaan oleh banyak orang.

Penerapan aturan perkuliahan daring telah meningkatkan volume penggunaan aplikasi Ilearn. Oleh karena itu, sebaiknya dilakukan peningkatan terhadap kinerja aplikasi Ilearn, terutama dari kapasitas dan kinerja server supaya tidak mengalami error ketika diakses secara bersamaan pada waktu yang sama. Selanjutnya perlu dilakukan penelitian lebih lanjut, terkait dengan menurunnya tingkat kepuasan pengguna seiring dengan bertambahnya masa studi.

\section{Ucapan Terima Kasih}

Penulis menyampaikan ucapan terima kasih kepada dosen dan mahasiswa Unand yang telah berkontribusi dalam membagikan dan mengisi kuesioner untuk penjaringan data penelitian ini serta dukungan dari rekan-rekan di UPT Perpustakaan Unand. 


\section{DAFTAR PUSTAKA}

Alenezi, A. (2018). Barriers to Participation in Learning Management Systems in Saudi Arabian Universities. Education Research International, 2018, e9085914. https://doi.org/10.1155/2018/9085914

Alqurashi, E. (2019). Predicting student satisfaction and perceived learning within online learning environments. Distance Education, 40(1), 133-148. https://doi.org/10.1080/01587919.2018.1553562

Arif, I., Handoko, H., Wahyudi, P., \& Sartika, S. (2020). ILearn V2 Panduan Pembelajaran Daring Bagi Dosen. RAH Multimedia.

Aulia, N. winanda, \& Aina, M. (2016). Pengembangan Multimedia Interaktif Menggunakan Camtasia Studio 8 Pada Pembelajaran Biologi Materi Kultur Jaringan Untuk Siswa SMA Kelas XI MIA. BIODIK, 2(1), Article 1. https://www.online-journal.unja.ac.id/biodik/article/view/3365

Biro Administrasi Akademik dan Kemahasiswaan. (2020). Rekapitulasi Mahasiswa Terdaftar Unand. Universitas Andalas.

Horvat, A., Dobrota, M., Krsmanovic, M., \& Cudanov, M. (2015). Student perception of Moodle learning management system: A satisfaction and significance analysis. Interactive Learning Environments, 23(4), 515-527. https://doi.org/10.1080/10494820.2013.788033

Juhary, J. (2014). Perceived Usefulness and Ease of Use of the Learning Management System as a Learning Tool. International Education Studies, 7(8), 23-34.

Kc, D. (2017). Evaluation of Moodle Features at Kajaani University of Applied Sciences - Case Study. Procedia Computer Science, 116, 121-128. https://doi.org/10.1016/j.procs.2017.10.021

Koh, J. H. L., \& Kan, R. Y. P. (2020). Perceptions of learning management system quality, satisfaction, and usage: Differences among students of the arts. Australasian Journal of Educational Technology, 36(3), 26-40. https://doi.org/10.14742/ajet.5187

Kuo, Y.-C., Walker, A. E., Schroder, K. E. E., \& Belland, B. R. (2014). Interaction, Internet self-efficacy, and self-regulated learning as predictors of student satisfaction in online education courses. The Internet and Higher Education, 20, 35-50. https://doi.org/10.1016/j.iheduc.2013.10.001

Menteri Pendidikan dan Kebudayaan RI. (2020). Surat Edaran Menteri Pendidikan dan Kebudayaan Tentang Pembelajaran Secara Daring da Bekerja dari Rumah dalam Rangka Pencegahan Penyebaran COVID-19. Menteri Pendidikan dan Kebudayaan RI.

Muilenburg, L. Y., \& Berge, Z. L. (2005). Student barriers to online learning: A factor analytic study. Distance Education, 26(1), 29-48. https://doi.org/10.1080/01587910500081269

Rahmadi, I. F., \& Hayati, E. (2020). LITERASI DIGITAL, MASSIVE OPEN ONLINE COURSES, DAN KECAKAPAN BELAJAR ABAD 21 MAHASISWA GENERASI MILENIAL. Jurnal Studi Komunikasi dan Media, 24(1), 14.

Rahman, T. (2020). Pembelajaran Daring di Era Covid-19 [Preprint]. SocArXiv. https://doi.org/10.31235/osf.io/7bfhk

Rustam, M. (2017). INTERNET DAN PENGGUNAANNYA. Jurnal Studi Komunikasi dan Media, 21(1), 12.

Sadikin, A., \& Hamidah, A. (2020). Pembelajaran Daring di Tengah Wabah Covid-19: (Online Learning in the Middle of the Covid-19 Pandemic). BIODIK, 6(2), 214-224. https://doi.org/10.22437/bio.v6i2.9759

Sheshasaayee, A., \& Bee, M. N. (2017). Evaluating user experience in moodle learning management systems. 2017 International Conference on Innovative Mechanisms for Industry Applications (ICIMIA), 735-738. https://doi.org/10.1109/ICIMIA.2017.7975562

Simanullang, N. H. S., \& Rajagukguk, J. (2020). Learning Management System (LMS) Based On Moodle To Improve Students Learning Activity. Journal of Physics: Conference Series, 1462, 012067. https://doi.org/10.1088/1742-6596/1462/1/012067

Sobron A. N, B. (2019). Persepsi Siswa Dalam Studi Pengaruh Daring Learning Terhadap Minat Belajar IPA. SCAFFOLDING: Jurnal Pendidikan Islam Dan Multikulturalisme, 1(2), 30-38. https://doi.org/10.37680/scaffolding.v1i2.117

Utami, Y. P., \& Cahyono, D. A. D. (2020). Study at Home: Analisis Kesulitan Belajar Matematika Pada Proses Pembelajaran Daring. Jurnal Ilmiah Matematika Realistik, 1(1), 20-26.

Yudiawan, A. (2020). Belajar Bersama COVID 19: Evaluasi Pembelajaran Daring Era Pandemi di Perguruan 
JURNAL STUDI KOMUNIKASI DAN MEDIA

Vol. 25 No. 1 Juni 2021 Hal : 81 - 92

Tinggi Keagamaan Islam Negeri, Papua Barat. Al-Fikr: Jurnal Pendidikan Islam, 6(1), 10-16. https://doi.org/10.32489/alfikr.v6i1.64 